\title{
Sustainable energy generation and use in SIDS and beyond-introducing the L3EAP online learning approach
}

\author{
Franziska Wolf ${ }^{*}$, Deisi V. Becker ${ }^{2,3}$, Walter Leal ${ }^{1}$, Jonathan Krink ${ }^{1}$, Julia Haselberger ${ }^{1}$ and Maria Kowald ${ }^{1}$
}

\section{*Correspondence:}

franziska.wolf@

haw-hamburg.de

${ }^{1}$ Research and Transfer

Centre Applications

of Life Sciences, Hamburg

University of Applied

Sciences, Ulmenliet 20,

21033 Hamburg, Germany

Full list of author information

is available at the end of the article

\begin{abstract}
Small Islands Developing States (SIDS), but also other developing countries especially in the Global South, still face distinctive challenges to ensure sustainable livelihoods for their current population as well as future generations. These include the access to and the production as well as provision affordable of energy. Despite a large potential for the production of renewable energy, availability and cost-effectiveness of energy efficiency technologies, the Global South still show a heavy reliance on fossil fuels to meet its energy demands, not least due to a lack of skilled human resources in the energy sector. Embracing ICT solutions, in the area of energy, can be a valuable crosscutting measure to promote education for sustainability and address the chronic human capacity problem that constrains the quicker uptake of sustainable energy technologies in SIDS. Drawing from a concrete project example involving Small Island Developing States, this paper explores the importance of open-access online courses for improved lifelong learning. The "Lifelong Learning on Energy Efficiency, Access and Security in African and Pacific Small Island Developing States", (short L3EAP) case study offers valuable insights into the practical development and implementation of a demand-driven approach. The L3EAP learning module addresses distinctive knowledge and technology needs and demands of developing countries in the field of sustainable energy production, renewable energy production, energy efficiency and energy security. In line with the global trend in digitalization, it is suggested that open-access online learning courses can boost education for sustainable development, reflected by the increasing number of openly accessible online learning opportunities and growing interest by further stakeholders groups, e.g. businesses and government staff. Finally, the paper also proposes some lessons recommendations and measures for integrating and utilizing ICT learning solutions in support of individual capacity-building and the sustainable socio-economic development in the Global South.
\end{abstract}

Keywords: Education for sustainability, Lifelong learning, Sustainable energy, OER, ICT4Dev, SIDS, Capacity-building

\section{Background}

One of the main issues discussed today refers to striving for sustainability. The argument in favor of a change is not new but has been on the agenda for at least 50 years (Gadotti 2008) on international, national and local levels. To Chalkley and Sterling (2011, p. 672), "the transition of society towards sustainability cannot be left to a handful of experts in

(c) 2016 Wolf et al. This article is distributed under the terms of the Creative Commons Attribution 4.0 International License (http:// creativecommons.org/licenses/by/4.0/), which permits unrestricted use, distribution, and reproduction in any medium, provided you give appropriate credit to the original author(s) and the source, provide a link to the Creative Commons license, and indicate if changes were made. 
sustainability, but will require a major transformation that affects all sectors of society and requires contributions from a wide range of professions and organizations". According to Wals and Jickling (2002), a serious didactic reorientation is needed, to identify, test and implement new and different ways of learning and teaching. Moreover, it becomes more and more important to consider local contexts of the intervention to be performed successfully. According to Sidiropoulos (2013), each person or group interprets sustainability through their own value lens, thus promoting messages of sustainability need to be positioned according to the receptivity of the audience.

There are multiple definitions of Education for sustainability (EfS). Yet a common train of thought appears to be the notion of enabling transformative change (see, for example, Cloud 2014). For example, one of the goals of education for sustainability is to instigate behavioral change (Moore 2005). However, the reference to education is not the same as of the last century, a reorientation of existing education needs to take place, taking into account principles and guiding practices of sustainability (Brunton 2006). There appears to be a distinctive need to better integrate formal and non-formal education, higher education, distance and online education, always adjusting for the various educational target groups. With specific reference to SIDS, Crossley and Sprague (2013: 94) argue that "there is much that the wider international community can learn from the ESD [Education for Sustainable Development; the author] experience of Small Island Developing States".

Paulo Freire (2013, p. 121) argues that it is necessary, above all, "that the student [who can be anyone; the author] takes the role of producer of his intelligence of the world and not just the recipient of transferred to it by the teacher". Harris et al. (2010) underscore the relevance of new forms of participation to revitalize interest in the processes of democratic decision-making, and also sensitize learners and teachers to emerging forms of participation, new ways to develop and express identities. Sustainability, according to Sidiropoulos (2013, p. 10) "is a journey of learning and each educational intervention contributes to building a greater understanding and guidance". Thus, there is not only an urgent need to understand how new knowledge emerges, but also how this new knowledge can be transferred and implemented to foster societal transformation and enable the world to finally enter a sustainable development pathway.

After briefly introducing the underlying methodology, i.e. case study research, this paper will briefly outline the relevance of sustainable energy for Small Island Developing States (SIDS) and current and emerging socio-economic challenges and opportunities for the sustainable development of SIDS. Moreover, this paper recalls the main theoretical concepts of capacity-building, international technology transfer as well as life-long learning in the field of energy and outlines their relevance in a SIDS context. Thirdly, a specific case study addressing key themes of education for sustainability (EfS) will be discussed and common entry points for sustainable lifelong learning and capacity-building programs focusing on themes such as energy access, energy security and energy efficiency are identified. Finally, it will be discussed to which extent these examples may resemble replicable solutions to further education on sustainable energy in SIDS, and some recommendations for further development of lifelong learning activities in SIDS will be given. 


\section{Methods}

Embracing ICT solutions can be a valuable crosscutting measure to promote education for sustainability and address the chronic human capacity problem that constrains the quicker uptake of sustainable energy technologies in Small Island Developing States (SIDS). Drawing from a concrete case study, an EU-funded project involving web-based capacity-building in Small Island Developing States, this paper explores the importance of open-access online courses that utilize open educational resources (OER) for improved lifelong learning. OER offer free access to knowledge, enable self-determined learning and interaction as they allow learners to change, amend and combine own knowledge, thoughts and ideas with the OER, thus facilitating self-determined learning as well the international exchange of knowledge and skills. Thus, such kind of open online courses can play an important role not only strengthening and building human capacities in less developed regions of the world, e.g. where awareness of and knowledge about sustainable energy technologies and climate change are lacking, but, in line with Freire's (2013) proposition also encourage and motivate learners to actively participate in the learning design, create and develop their own knowledge of the world.

By means of a case study of the "Lifelong Learning on Energy Efficiency, Access and Security in African and Pacific Small Island Developing States", (short L3EAP) project activity, valuable insights into the practical development and implementation of such a demand-driven approach are explored. The case illustrates how the online module is designed around learners' needs and demands, how it encourages, even requires, active participation in the learning process. The L3EAP learning module is grounded in distinctive knowledge and technology needs and demands of developing countries in the field of sustainable energy production, renewable energy production, energy efficiency and energy security. This will be elaborated in the next two chapters which provide the overall context of this case study research. By putting the case of the L3EAP online learning module in context, its relevance to education for sustainability can be described from multiple perspectives, i.e. relating to the relevance of sustainable energy particularly for SIDS and the crucial role of capacity-building for these islands.

Moreover, in line with the global trend, or context of, in digitalization, it will be argued that open-access online learning courses can boost education for sustainable development, reflected by the increasing number of openly accessible online learning opportunities and growing interest by stakeholder groups outside academia, e.g. businesses, government staff and civil society.

\section{Relevance of sustainable energy for SIDS}

Many small island developing states are highly vulnerable to global and environmental change when their access to affordable energy is constrained or not existent at all (see also Table 1). Relying on the import of fossil fuels, SIDS' national budgets are chronically constrained, leaving little room for sustainable investments, e.g. sustainable energy production or adaptation to climate and environmental change. In this respect, SIDS are distinctively marked by their high cost of energy in general, combined with price fluctuations, electrical transmission losses due to aging infrastructure and further constraints. It is claimed that prices of petroleum products are much higher in SIDS than in other regions of the world, in Pacific SIDS sometimes as much as $200-300 \%$. As a result, 
Table 1 Summary table of SIDS energy issues

\begin{tabular}{|c|c|c|c|}
\hline & High & Low & Comments \\
\hline Fossil fuel dependence & $\checkmark$ & & $\begin{array}{l}\text { Most electricity is sourced from diesel-powered } \\
\text { generators and transport is solely powered by } \\
\text { fossil fuels }\end{array}$ \\
\hline Biofuel use & & $\checkmark$ & $\begin{array}{l}\text { Limited capacity and involves significant risks for } \\
\text { smaller SIDS as biofuel production could raise the } \\
\text { price of energy crops, making them more vulner- } \\
\text { able as import dependent countries }\end{array}$ \\
\hline Access to electricity & $\checkmark$ & & $\begin{array}{l}\text { Increasing access for rural areas has been a signifi- } \\
\text { cant development by SIDS over the last } 20 \text { years }\end{array}$ \\
\hline Energy costs & $\checkmark$ & & $\begin{array}{l}\text { Pacific Islands spend on average up to } 20 \% \text { of their } \\
\text { household incomes on energy needs }\end{array}$ \\
\hline $\begin{array}{l}\text { Total energy supplied by modern } \\
\text { renewables }\end{array}$ & & $\checkmark$ & $\begin{array}{l}\text { With some exceptions in larger island with hydro- } \\
\text { electric capacity }\end{array}$ \\
\hline Electrical transmission losses & $\checkmark$ & & $\begin{array}{l}\text { Aging infrastructure and maintenance are the } \\
\text { predominant issues here }\end{array}$ \\
\hline Potential for renewables & $\checkmark$ & & $\begin{array}{l}\text { Wind, solar, tidal, and geothermal have huge poten- } \\
\text { tial for SIDS }\end{array}$ \\
\hline $\begin{array}{l}\text { Investment and planning in } \\
\text { renewables }\end{array}$ & $\checkmark$ & & $\begin{array}{l}\text { Most SIDS have policy objectives and are seeking } \\
\text { investments to expand renewable energy and } \\
\text { diversify supplies }\end{array}$ \\
\hline
\end{tabular}

UNEP (2014b: 11)

households in the Pacific might have to spend up to $20 \%$ of their disposable income on energy. World market prices of crude oil fluctuate largely, and imported energy resources would need to be paid in foreign currencies whose exchange rates vary as well, placing additional burden on SIDS national accounts (UNEP et al. 2012; UNEP 2014a, b). The GEO SIDS Outlook (UNEP 2014a, b) provides a summary of key energy issues for SIDS.

Taking into account the anticipated impacts of future climate change and related temperature rise, energy demand for heating is expected to shrink, but for cooling it would increase. Concerning the provision of energy, energy sources and technologies are expected to be impacted both positively and negatively, e.g. depending on wind conditions, technological processes, e.g. cooling, or location of the production unit, e.g. in exposed places or rather protected locations. It is suggested that the intactness and reliability of pipeline infrastructure and electric grids may be affected as well (Arent et al. 2014).

However, many SIDS have not yet exploited their often extraordinary renewable potential. Utilizing the island's solar, wind, wave, biomass and geothermal renewable energy sources may relieve the burden of high energy costs as well as reduce emissions and related environmental and health impacts. In addition, these low carbon, climatesmart technologies may contribute to more sustainable island energy systems-and may even transform islands into energy exporters. For example, the Bahamas are claimed to have a potential of more than 100TWh per year with technology appropriate for the island, exceeding the island's current energy demand by as much as 47 times (UNEP 2014a).

Yet despite the need to reduce the heavy reliance on fossil fuels and the worldwide promotion of renewable energy and energy efficiency during this current UN Decade of Sustainable Energy for All (2014-2020), the adoption of sustainable technologies appears to progress slowly across sectors and governance levels in SIDS and beyond. The reasons 
for the slow pace relate to the many barriers that hamper development and implementation, e.g. technical constraints, lack of finance and investment, limited technology transfer, appropriate scales of sustainable technologies, a lack of appropriate institutional and regulatory frameworks and little replication and adaptation of successful initiatives and projects. Moreover, human resources resemble a crucial bottleneck since a lack of qualified human resources hinders not only the introduction of renewable and energy efficient technologies but also the wider application of appropriate technology for small islands and, even more importantly, the maintenance of those technologies. Key SIDS development reports also suggest that indigenous technological knowledge and local innovation may be observed in small islands, yet information and knowledge sharing on these aspects is low (UNEP et al. 2012; UNEP 2014a, b).

\section{Capacity-building as bottleneck to sustainable societal transformation in SIDS}

In future, small island nations may have to face a set of SIDS-specific emerging socioeconomic challenges, among them the need for appropriately skilled capacities as well as a transition to renewable energy systems to support sustainable island livelihoods. In the frame of the UNEP Foresight Process, in which the most pressing emerging environmental issues and appropriate solutions were analyzed on global as well as on SIDS level, 20 emerging socio-economic challenges for the sustainable development of SIDS were identified (see Table 2). Fostering human capacities is one explicit cross-cutting issue as the welfare of a country is fundamentally connected to the productivity of its people which in turn is connected to professional skills and appropriate capacity-building concerning formal education, but also informal approaches such as distinctive training programmes on SIDS specific demands. Adequate and appropriate skills may help building and strengthening island sustainability. Among the range of environmental issues, harnessing renewable energy also urgently requires policy attention and solutions. Moreover, especially in rural regions renewables may provide valuable opportunities as access to electricity is lacking, for example, 70 per cent of the pacific Island population (UNEP 2014b).

To make best use of the recent analyses to guide SIDS policy-making and their critical transformation towards sustainability, four possible island-centric development paths, or themes, may be mentioned which a SIDS may adapt to its distinctive needs: a bluegreen economy, technology leapfrogging, priority to island community and culture, and reconnecting with nature. Developed in the course of the SIDS Outlook process, these possible futures may serve as means to foster discussion, reflection and consultation among SIDS policy-makers and a wider group of stakeholders, guiding SIDS in their transition to sustainable island states (UNEP 2014a).

\section{Results and discussion}

Ongoing need for promotion of sustainable energy and local capacity-building

Despite the fact that the before mentioned needs and constraints of SIDS in the field of energy are addressed on multiple levels already, there is a continued need for upscaling and widening efforts to many more regions and island nations in particular. Global initiatives, such as UNEP's established "Sustainable Energy4All (SE4ALL)" initiative, the International Renewable Energy Agency's (IRENA) recent “SIDS Lighthouse Initiative”, 
Table 2 The 20 SIDS' environmental issues

\begin{tabular}{|c|c|}
\hline Issue ID & Issue title \\
\hline \multicolumn{2}{|c|}{ Cross-cutting issues } \\
\hline 001 & Beyond GDP_Developing appropriate indicators for SIDS'Sustainable Development \\
\hline 002 & Unique Human Capacities for Island Sustainability \\
\hline 003 & $\begin{array}{l}\text { Synergizing Indigenous and Local Knowledge and Modern Sciences as a Basis for Sustainable Island } \\
\text { Development }\end{array}$ \\
\hline \multicolumn{2}{|c|}{ Rehabilitating Biodiversity and Ecosystem Services } \\
\hline 004 & The Continued Threat of Invasive Alien Species \\
\hline 005 & Averting the Loss of tropical Montane Cloud Forest \\
\hline 006 & Breakdown of sand and Sediment Budget due to Biodiversity Loss \\
\hline 007 & Decline of Agrobiodiversity and Ecosystem Functions Affecting Food and Livelihood Security \\
\hline 008 & Overfishing and Potential Collapse of Inshore Marine Ecosystems \\
\hline \multicolumn{2}{|c|}{ Sustainable use of natural resources } \\
\hline 009 & Degradation and Scarcity of Freshwater Resources \\
\hline 010 & Coastal Squeeze and Loss of Associated Ecosystem Services \\
\hline 011 & Reaching the Limit of Land Capacity \\
\hline 012 & Harnessing Renewable Energy Opportunities \\
\hline 013 & Balancing the Opportunities and Risks of Exploring SIDS' Unexploited Natural Resources \\
\hline 014 & Developing an Ocean-based Green Economy \\
\hline \multicolumn{2}{|c|}{ Managing Threats from Chemicals and Waste } \\
\hline 015 & Globally emitted Contaminants Affecting SIDS \\
\hline 016 & Indiscriminate and Increasing Use of Pesticides \\
\hline 017 & Greening the Waste Sector: Turning Waste into Opportunities in SIDS \\
\hline \multicolumn{2}{|c|}{ Addressing climate change and its impacts } \\
\hline 018 & Disproportionate Impact of Climate Change and Sea-level Rise in SIDS \\
\hline 019 & Intensification of Extreme Events and External Shocks and Increasing Vulnerability of SIDS \\
\hline 020 & Climate and Environmental Change Driving Population Displacements \\
\hline
\end{tabular}

regional energy policy frameworks, such as the "Framework for Action on Energy Security in the Pacific (FAESP)" or the "SIDS DOCK", an initiative of the Alliance of Small Island States (AOSIS), as well as national energy policies foster the transition of SIDS to transform their energy sectors towards sustainable energy production and use. Moreover, a multitude of infrastructure and development projects supports this transformation on national levels. As a co-benefit of all these activities, SIDS improve adaptation to a changing climate. Capacity building, focusing on lifelong learning in the area of energy, can resemble one distinctive crosscutting measure to address the chronic human capacity problem that constrains a quicker uptake of sustainable energy technologies in (SIDS DOCK 2011; Singh et al. 2013; UN 2012; IRINA 2014).

A set of theoretical concepts are discussed in the following who are closely related and to some extent also overlap. Distinctive aspects, which relate to transformational aspects of education for sustainability, are highlighted and later linked to the particular case study:

To date, there is no clear definition, but many definitions of capacity and capacity building in the literature. A rather broad definition suggests "capacity can be defined as the ability to perform tasks and produce outputs, to define and solve problems, and make informed choices" (EuropeAid 2007). The Agenda 21 (UNCED 1992) refers explicitly to 
the relevance of country context and an assessment of local needs for appropriate capacity building action: "Specifically, capacity building encompasses the country's human, scientific, technological, organizational, institutional and resource capabilities. A fundamental goal of capacity building is to enhance the ability to evaluate and address the crucial questions related to policy choices and modes of implementation among development options, based on an understanding of environment potentials and limits and of needs perceived by the people of the country concerned" (Panitsidou et al. 2012). This definition implies that any capacity-building action needs to address the target groups' and corresponding location specific needs and demands to build local capacity in a sustainable, appropriate and targeted manner.

Lifelong learning is also closely connected with capacity-building. Many definitions of lifelong learning (LLL) exists. Common to all, rather similar definitions, are a distinctive focus on improving knowledge, skills and qualifications and reference to a wide range of possible formats: General education, vocational education and training, nonformal education and informal learning. The European Commissions Lifelong Learning Programme offers the following definition for LLL: "This refers to all general education, vocational education and training, non-formal education and informal learning undertaken throughout life, resulting in an improvement in knowledge, skills and competences within a personal, civic, social and/or employment-related perspective. It includes the provision of counselling and guidance services" (UNESCO/UNEVOC 2015). Moreover, the motivation for LLL may be grounded not only in personal, but social and professional reasons as well. It is thus concluded that LLL offers a distinctive social-economic value and has a distributional, stabilizing as well as developmental function (Panitsidou et al. 2012). In a development aid context, it could be suggested that LLL activities may thus serve similar functions, but despite an uncontroversial positive correlation between education and earnings, the actual extent to which the former influences the latter is difficult to determine and thus subject to interpretation (Psacharopoulos 1994). However, some also criticize European education policy and its focus on LLL, claiming that it is rather a slogan for the new millennium and means to pursue various, sometimes conflicting interests, "legitimizing economic imperialism and reduction of welfare services" (Panitsidou et al. 2012). Again, translated to a developing context, this leaves a somewhat negative connotation as it may offer an argument for shifting national financial resources to superficially more cost-effective causes such as renewable energy, which implies an image of sustainability.

In spite of the blurred theoretical foundations, and despite many other developmental and environmental challenges that developing nations face, knowledge transfer and learning about appropriate sustainable technologies, combined with transfer of the respective technologies, resembles an additional important aspect for consideration in SIDS. Generally, the objectives of technology transfer (TT) are the acquisition of appropriate technology and widespread diffusion (Mannke 2012). Todays terminology is more inclusive of intangible items such tacit knowledge, i.e. knowledge that is embedded in people and processes (Cantwell 2009). International technology transfer (ITT) follows similar line of thoughts, yet with an additional analytic lens that looks at the directions and types of transfers between involved actors (Mannke 2012). In terms of international climate technology transfer, which comprises both mitigation and adaptation 
technologies, the prevailing paradigm refers to mainly North-South flows of technology and financial investments, e.g. in the frame of bilateral and development aid. According to another, complementary paradigm ITT may also take place among groups of countries, e.g. SIDS or LDCs, from developing to developed nations [South-North] as well as among developing countries [South-South] (Brewer 2008). Relating to the intangible dimension of knowledge, Kathuria (2002) suggests a further aspect that analyses of ITT need to address: the movement of people.

Concerning energy-related technology transfer, both paradigms may be observed in SIDS. In the frame of the before-mentioned global initiatives SE4ALL and IRENA's Lighthouse Actions, technology and financial resources flow from developed countries to developing countries. Other initiatives such as the FAESP or SIDS DOCK facilitate the collaboration and exchange of knowledge, experiences and appropriate technologies within regions or among certain groups. Further climate change mitigation initiatives such as the Pacific Islands Greenhouse Gas Abatement through RE project (PIGGAREP) provided funds for dedicated small islands such as Cook Islands, Fiji, Kiribati, Nauru, Niue, Papua New Guinea, Samoa, Salomon Islands, Tongam, Tuvalu and Vanuatu (Bijay et al. 2013).

Relating to the aspect of capacity-building in the field of sustainable energy in particular, recommendations for SIDS include a set of lifelong learning measures such as dedicated capacity-building workshops, training programmes or the extension of university curricula to better prepare student for employment in green economic sectors. These short-term and longer-term measures should focus on building and strengthening interdisciplinary and multi-disciplinary skills and knowledge as required in sustainability-related jobs. In this respect, information and communication technologies (ICT) and related e-learning and online courses can offer great opportunities especially for SIDS and their people, especially if they are openly accessible (Niyibizi and Komakech 2013; UNEP 2014b). One example of how ICT may utilized to foster capacity-building and knowledge transfer to distance regions is a freely accessible online resource for renewable energy education and training, the IRELP portal. It has been developed by the International Renewable Energy Agency (IRENA). Besides offering a range of education and training measures, IRELP features also a library of renewable energy training materials, a database of webinars, a platform of electronically supported learning for students and a forum designed to facilitate collaboration between educational institutions. Moreover, an IRELP forum facilitates institutional collaboration through providing assistance for the development of new educational curricula with a particular focus on programs in developing countries (IRINA 2014).

Moreover, a sample of SIDS have already a track record of successful climate technology transfer and capacity building projects addressing themes such as renewable energy, energy access, energy efficiency and energy security. Often, international donors often provide financial and technical assistance and undertake these projects in collaboration with selected countries and actors on multiple levels, from national to local. A distinctive European collaboration scheme is the EDULINK programme addressing higher education institutions (HEI) in the African-Caribbean-Pacific (ACP) region (see http:// www.acp-edulink.eu). Its global objectives address distinctive development needs in the ACP region, i.e. fostering sustainable growth, improving educational quality addressing 
distinctive needs of local labor markets and building local capacity through promoting cooperation of HEI within the ACP region, between ACP and European HEI and, finally, the inter-cultural dialogue and understanding. In this, the programme seeks to strengthen the institutional capacity of ACP HEIss on management/administration and academic levels. One ongoing project example in the frame of this international collaboration scheme will be presented in more detail in the following.

Towards the delivery of high-quality lifelong learning opportunities: the case of the L3EAP online learning module

As providers of high quality education, universities generally resemble important actors in building human capacities. Moreover, there is an acknowledged need for appropriate lifelong learning schemes that involves capacity building also for higher education institutions (HEI) to better address distinctive knowledge and technology needs and demands of SIDS. In this respect, transnational teaching modules and e-learning, may offer valuable opportunities particularly for SIDS to integrate topics related to renewable energy, energy efficiency, access and security in their curricula and at the same time strengthening their own institutional capacity to deliver courses in these topics.

The project L3EAP, short for LifeLong Learning for Energy Security, Access and Efficiency in African and Pacific SIDS, aims to increase the institutional capacity of universities in African, Caribbean and Pacific Group of States (ACP) SIDS to deliver high-quality lifelong learning courses on the topics of energy access, security and efficiency. By its focus on energy security, access and efficiency, L3EAP addresses a topic that is most relevant for the local labor market and the socio-economic development of the involved SIDS (further details see http://www.project-13eap.eu/). Coordinated by the Hamburg University of Applied Sciences, Germany, the project has been funded by the EDULINK Programme, an EU programme for cooperation between the European Union and the ACP region (Africa, Caribbean, and Pacific).

- Project activities: assessment of needs of participating institutions as well as businesses; identification of entry points for LLL in university curricula; development of needs-oriented LLL modules, exchange of experiences on LLL within partnership and beyond; learning-by-doing when developing and implementing a hands-on transnational pilot teaching module.

As such, L3EAP fosters both, South-South as well as South-North collaboration, with the opportunity on benefitting from an openly accessible technological learning platform of the northern lead partner. The project is characterized by its emphasis on facilitating knowledge and technology transfer between universities and to national stakeholders from the business environment and beyond, thereby supporting introduction of sustainable technologies and approaches to SIDS markets. For example, the local capacitybuilding seminars, held in Fiji, Mauritius and Germany, address distinctive needs of local stakeholders in the universities or outside. For example, one recent Mauritian capacitybuilding seminar offered lectures on renewable energy, energy access and security as well as energy management in SIDS, also addressing environmental issues. The following figure illustrates the overall conceptual approach of the L3EAP project (see Fig. 1). 


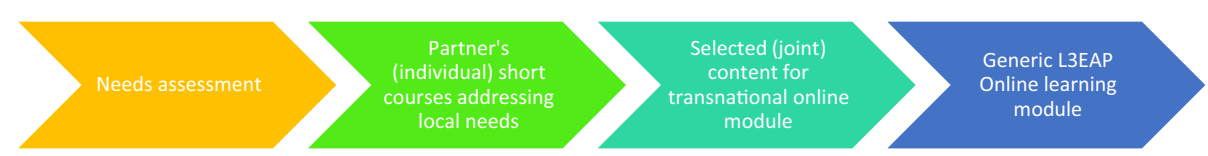

Fig. 1 The L3EAP/HOOU needs-based course-design. Source: own compilation

Three characteristic features of the L3EAP transnational online learning course are (1) a vast integration of interactive functionalities to increase the intrinsic motivation of the distant learner; (2) the provision of an openly accessible learning environment that eliminates the barrier of access to knowledge and through this also offers access to a global learning community, and (3) the use of open educational resources (OER), i.e. material that can be freely disseminated and further processed by the learner. All project partners contribute with content and support the technical implementation, with the integration of various types of audio-visual media, e.g. video clips, animated slides, online discussions, quizzes, case studies etc. Concerning the generic content, the generic online course comprises six thematic modules (see curriculum Fig. 2). The learning design comprises a modular assignment sequence with increasing complexity, thematically moving "outside-in" from global energy context to actionable projects in SIDS. By following this storyline, learners can acquire the knowledge and skills to develop their own energy project proposals which address a concrete energy and SIDS related problem, i.e. enabling these learners to build their own capacity by developing skills to address a reallife problem.

In terms of education for sustainability and in relation to the opportunities ICT technology may offer in that it serves to bridge the distance between learners and teachers, academia and practitioners, the younger and older generations, the generic L3EAP online learning module is designed in a way that caters the various needs of the distinctive target group (i.e. lead users), i.e. addressing various prior levels of knowledge, various learning styles and local contexts. In this respect, one lead use case has been defined, describing key features of those type of learners whose particular needs and demands have to be met by an appropriate learning design. The lead user of the online module

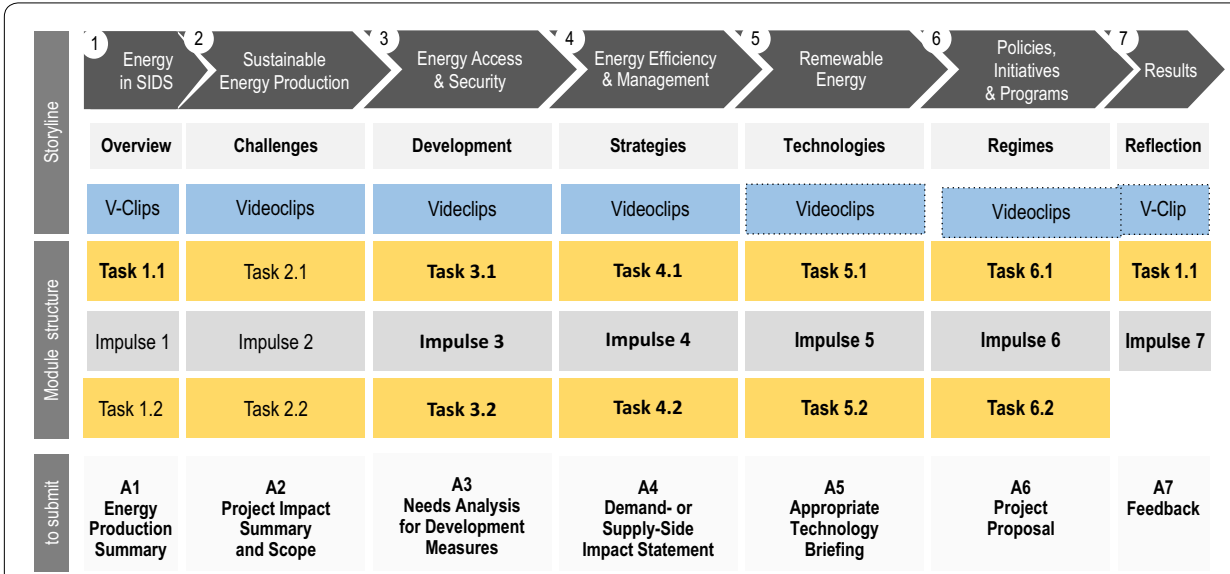

Fig. 2 Storyline and curriculum: Sequence of six increasingly complex modular assignment cycles. Source: own compilation 
would have practical use for energy project management know-how. Two further use cases have also been defined, these resemble additional user groups to whom the content may be useful. Course participants enrolling in these self-learning course modules in English language are expected to come from the partner institutions' home countries, but also from other SIDS and developing countries.

The didactic concept followed in the frame of the L3EAP module will thus facilitate problem-based learning and flipped classroom settings, complemented by a set of selfassessment elements and the option to award a certificate upon completion of the full module. To optimally guide the learners into and through the modules and to reduce the drop-out rate, the project aims to provide a self-explanatory environment with the appropriate level of information and instruction. To achieve a high degree of personalization to bridge the digital distance, the instructors, but also the learners, could be visualized, e.g. by means of a picture and/or a short profile. However, due attention needs to be paid to constraints and limitation of technology, learners as well as teachers (see, for example, Webste and Hackley 1997; Muilenburg, and Berge 2005; Kreijns et al. 2003).

Finally, due to its open access design, the transnational e-learning module on energy efficiency, energy access and security can be utilized by everyone who has access to the internet. To ensure sustainability of this distinctive learning module, this pilot module is in a first step implemented using the Moodle learning platform technology that offers somewhat limited access, with the prospect of embedding it in late 2016 into the Hamburg Open Online University (HOOU), a openly accessible internet-based learning environment, sustained by the Free and Hanseatic City of Hamburg, so that the course can be upscaled, i.e. allowing much more participants to participate in the pilot module (HAW 2015).

In summary, the main learning objectives of the L3EAP online course need to consider the variety of learners', each with individual backgrounds, and the overall context in which the continued promotion of sustainable energy is one of the main goals. For this reason, the online course aims to achieve no more but also no less than the following:

- Raising awareness and understanding of energy production and use and related emission of greenhouse gases such as $\mathrm{CO} 2$ that drive global climate change;

- Building skills to identify implementation scenarios for renewable energy, with particular relevance to a small island developing state context;

- Strengthening capacities in renewable energy, energy efficiency and distribution;

- Advancing awareness and understanding of market opportunities and properties of renewable energy systems.

\section{Conclusions and recommendations}

In the light of the developmental, economic, environmental and climate-related challenges that SIDS have to face, there is a recognized need for capacity-building to strengthen the resilience and the adaptive capacity of small island states and their people. Especially regarding the issue of energy access, energy security and energy efficiency remain of paramount importance to SIDS in their development towards becoming more sustainable islands that can more successfully tackle global challenges such as the impacts of current climate variability and future climate change. Through 
their extraordinary endowment with solar, wind, biomass, geothermal and wave energy potential, renewables offer many opportunities to improve island livelihoods and socioeconomic wellbeing especially in SIDS.

Not limited to SIDS, matters of energy access, energy security and energy efficiency are being addressed in many regions of the world, yet much more needs to be undertaken to truly foster the transition towards more sustainable energy systems that may in the long run benefit developing countries of the Global South. Moreover, these issues, especially energy efficiency and energy security, in particular related to the phenomenon Energiewende, i.e. the large-scale integration of renewable energy in current energy systems, are of relevance to the Global North as well.

Knowledge and technology transfer can resemble valuable measures to introduce and spread appropriate technologies and build or strengthen capacities where needed. Embedded in lifelong learning frameworks that tackle distinctive local needs and also embrace the unique opportunities of ICT and e-learning to reach out to a wider number of learners and than in traditional, limited classroom settings and possibly enabling new collaboration between learners but also lecturers and other universities utilizing in online learning, these measures may offer a substantial contribution to the sustainable development of SIDS and beyond (Hogan and Kedrayate 2010; Diki 2013). The successful LLL project L3EAP was highlighted that might serve as example and inspiration what may work well in and for small islands that pursue such an approach to tackle a serious societal challenge.

Finally, it is argued that more effort should be placed in capacity building, focusing on lifelong learning in the area of energy, is a valuable crosscutting measure to address the chronic human capacity problem that constrains the quicker uptake of sustainable energy technologies in SIDS, and promote the cause of sustainable energy to a global learning audience.

\section{Abbreviations}

EfS: education for sustainability; ESD: education for sustainable development; SIDS: Small Island Developing States; L3EAP: ACP project LifeLong Learning for Energy Security, Access and Efficiency in African and Pacific SIDS; ICT: internet and communication technologies; LLL: lifelong learning; OER: open educational resources.

\section{Authors' contributions}

FW drafted the basic version, with support from JH and MK; FW was supported by DVB, JK and WL in the finalization of the full paper. All authors read and approved the final manuscript.

\section{Author details}

${ }^{1}$ Research and Transfer Centre Applications of Life Sciences, Hamburg University of Applied Sciences, Ulmenliet 20, 21033 Hamburg, Germany. ${ }^{2}$ Management School, Universidade Federal do Rio Grande do Sul, Washington Luiz, 855, Porto Alegre, Brazil. ${ }^{3}$ Universidade Federal do Rio Grande do Sul, Av. Paulo Gama, 110 - Bairro Farroupilha, Porto Alegre, Rio Grande do Sul, Brazil.

\section{Acknowledgements}

This paper is based on a previous version produced for the International Conference on Energy, Environment and Climate Change (ICEECC 2015), held in Mauritius from 8-9 July 2015, it was included in the unpublished conference proceedings and has been further developed for publication in the Brazilian Journal of Science and Technology: Call for Papers for a Special Issue on Education for Sustainability. It has been written in the frame of the ACP project LifeLong Learning for Energy Security, Access and Efficiency in African and Pacific SIDS (L3EAP)/FED/2013/320-080 and the project "Digital Literacy in Sustainable Erngy Production" in the frame of the Hamburg Open Online University. The authors gratefully acknowledge the valuable feedback of the anonymous reviewers.

\section{Competing interests}

The authors declare that they have no competing interests.

Received: 22 October 2015 Accepted: 26 February 2016

Published online: 07 March 2016 


\section{References}

Arent DJ, Tol RSJ, Faust E, Hella JP, Kumar S, Strzepek KM, Tóth FL, Yan D (2014) Key economic sectors and services. In: Field CB, Barros VR, Dokken DJ, Mach KJ, Mastrandrea MD, Bilir TE, Chatterjee M, Ebi KL, Estrada YO, Genova RC, Girma B, Kissel ES, Levy AN, MacCracken S, Mastrandrea PR, White LL (eds) Climate Change 2014: impacts, adaptation, and vulnerability. Part A: global and sectoral aspects. Contribution of Working Group II to the Fifth Assessment Report of the Intergovernmental Panel on Climate Change. Cambridge University Press, Cambridge, United Kingdom and New York, NY, USA, pp 659-708

Bijay P, Schulte V, Prasad S (2013) An overview of climate-smart technologies in the Pacific Region. In: Leal Filho W, Mannke F, Mohee R, Schulte V, Surroop D (eds) Climate-smart technologies: Integrating renewable energy and energy efficiency in mitigation and adaptation responses. Springer, Berlin, Heidelberg, pp 3-18

Brewer TL (2008) Technology transfers and climate change: international flows, barriers, and frameworks. In: Brainard L, Sorkin I (eds) Brookings Trade Forum 2008/2009: climate change, trade, competitiveness is a collision inevitable?. Brookings Institution Press, Washington, DC, pp 93-119

Brunton K (2006) Education for sustainable development: principles for curriculum development in business subject areas. Investig Univ Teach Learn J 3(2):36-46

Cantwell J (2009) Innovation and information technology in the MNE. In: Rugman AM, Verbecke A (eds) The Oxford handbook of international business, 2nd edn. Oxford University Press, Oxford

Chalkley B, Sterling S (2011) Hard times in higher education: the closure of subject centres and the implications for education for sustainable development (ESD). Sustain J 3:666-677

Cloud J (2014) The essential elements of education for sustainability (EfS). Editorial Introduction from the Guest Editor Sustain Educ J 6. http://www.jsedimensions.org/wordpress/wp-content/uploads/2014/05/Cloud-Jaimie-JSE-May2014-PDF-Ready2.pdf. Accessed 1 Oct 2015

Crossley M, Sprague T (2013) Education for Sustainable Development: Implications for small island developing states (SIDS). Int J Educ Dev 35:86-95

Diki D (2013) International collaboration of distance learning universities for online learning in Indonesia. LUX: A Journal of Transdisciplinary Writing and Research from Claremont Graduate University, 2(1) 12. http://scholarship.claremont. edu/cgi/viewcontent.cgi?article=1011\&context=lux. Accessed 1 Oct 2015

EuropeAid (2007) Institutional assessment and capacity development: why, what and how?, tools and methods series, reference document No 1. Office for Official Publications of the European Communities, Luxembourg

Freire P (2013) Pedagogia da Autonomia: saberes necessários à prática educativa. Terra e Paz, São Paulo, Brazi

Gadotti M (2008) Educar para a sustentabilidade. Inclusão Soc 3(1):75-78

Harris A, Wyn J, Younes S (2010) Beyond apathetic or activist youth. 'Ordinary'young people and contemporary forms of participation. YOUNG Nordic J Youth Res 18(1):9-32

HAW (2015) Open Educational Resources. http://www.haw-hamburg.de/qualitaet-in-der-lehre/hoouhaw/open-educational-resources.html. Accessed 15 Aug 2015

Hogan R, Kedrayate A (2010) E-learning: a survival strategy for developing countries. Paper presented to the Eleventh Annual Conference of the Sir Arthur Lewis Institute of Social and Economic Studies, Trinidad and Tobago, March 24-26. http://citeseerx.ist.psu.edu/viewdoc/download?doi=10.1.1.477.1612\&rep=rep1\&type=pdf. Accessed 1 Oct 2015

IRINA (2014) IRENA lighthouse initiative. http://www.irena.org/menu/index.aspx?mnu=Subcat\&PriMenulD=44\&Cat|D=1 $12 \&$ Subcat $\mid \mathrm{D}=458$. Accessed 15 March 2015

Kathuria V (2002) Technology transfer for GHG reduction: a framework with application to India. Technol Forecast Soc Change J 69(4):405-430

Kreijns K, Kirschner PA, Jochems W (2003) Identifying the pitfalls for social interaction in computer-supported collaborative learning environments: a review of the research. Comput Human Behav J 19(3):335-353

Mannke F (2012) Fostering international technology transfer through climate technology networks between European and Latin American Universities. Latin American Business Rev 13(3):171-197. doi:10.1080/10978526.2012.730018

Moore J (2005) Seven recommendations for creating sustainability education at the university level: a guide for change agents. Int J Sustain High Educ 6(4):326-339

Muilenburg LY, Berge ZL (2005) Student barriers to online learning: a factor analytic study. Distance Educ J 26(1):29-48

Niyibizi A, Komakech A (2013) Climate change mitigation in developing countries using ICT as enabling tool. In: Leal Filho W, Mannke F, Mohee R, Schulte V, Surroop D (eds) Climate-smart technologies: integrating renewable energy and energy efficiency in mitigation and adaptation responses. Springer, Berlin Heidelberg, pp 19-32

Panitsidou et al (2012) European Union policies on lifelong learning: in-between competitiveness enhancement and social stability reinforcement. In: Procedia-Social and Behavioral Sciences, Special Issue 4th world conference on educational sciences (WCES-2012), 2-5 February 2012, Barcelona, Spain, vol 46, pp 548-553

Psacharopoulos G (1994) Returns to investment in education: a global update. World Dev J 22(9):1325-1343

Sidiropoulos E (2013) Education for sustainability in business education programs: a question of value. J Clean Prod 85:472-487

SIDS DOCK (2011) SIDS DOCK. Support Program for Small Island Developing States. http://www.esmap.org/node/3033m. Accessed 3 Mar 2015

Singh A et al (2013) Sustainable energy development in the Pacific: The evolution of energy frameworks and national policies. In: Leal Filho W, Mannke F, Mohee R, Schulte V, Surroop D (eds) Climate-smart technologies. Integrating renewable energy and energy efficiency in mitigation and adaptation responses. Springer, Berlin, Heidelberg, pp $129-140$

UN (2012) Sustainable energy for all. A framework for action. http://www.se4all.org/wp-content/uploads/2013/09/ SE_for_All___Framework_for_Action_FINAL.pdf. Accessed 3 Mar 2015

UNCED (1992) Agenda 21. In: United Nations conference on environment and development, Rio de Janeiro, Brazil, 3-14 June 1992. https://sustainabledevelopment.un.org/content/documents/Agenda21.pdf. Accessed 22 Mar 2015

UNEP (2014a) Global environment outlook. Small Island Developing States. United Nations Environment Programme (UNEP), Division of Early Warning and Assessment, Nairobi, Kenya 
UNEP (2014b) Emerging issues for Small Island Developing States. Results of the UNEP foresight process. United Nations Environment Programme (UNEP), Nairobi, Kenya

UNEP, UN DESA, FAO (2012) SIDS-FOCUSED Green economy: an analysis of challenges and opportunities. http://www. unep.org/greeneconomy, www.unep.org/regionalseas. Accessed 5 Mar 2015

UNESCO/UNEVOC (2015) TVETipedia glossary. Lifelong Learning (LLL). http://www.unevoc.unesco.org/ go.php?q=TVETipedia+Glossary+A-Z\&term=Lifelong+learning. Accessed 23 Mar 2015

Wals AEJ, Jickling B (2002) Sustainability in higher education: from doublethink and newspeak to critical thinking and meaningful learning. High Educ Policy J 15:121-131

Webste J, Hackley P (1997) Teaching effectiveness in technology-mediated distance learning. Acad Manag J. http://amj. aom.org/content/40/6/1282.short. Accessed 1 Oct 2015

Submit your manuscript to a SpringerOpen ${ }^{\circ}$ journal and benefit from:

- Convenient online submission

- Rigorous peer review

- Immediate publication on acceptance

- Open access: articles freely available online

- High visibility within the field

- Retaining the copyright to your article

Submit your next manuscript at $\boldsymbol{s p r i n g e r o p e n . c o m ~}$ 